\title{
Bazı Yulaf Çeșitlerinin (Avena sativa L.) Farklı Lokasyonlarda Verim ve Kalite Parametrelerinin Belirlenmesi
}

\author{
*ismail NANELi, Mehmet Ali SAKIN \\ Gaziosmanpașa Üniversitesi, Ziraat Fakültesi, Tarla Bitkileri Bölümü, Tokat \\ *Sorumlu Yazar e-mail: ismail.naneli@gop.edu.tr
}

\section{Öz}

Bu çalıșma, bazı yulaf çeșitlerinin Tokat-Kazova ve Samsun-Havza lokasyonlarında verim ve kalite unsurlarının belirlenmesi amacıyla 2015-2016 vejetasyon döneminde yürütülmüștür. Araștırmada materyal olarak 15 yulaf (Avena sativa L.) çeșidi kullanıımıștır. Deneme, Tesadüf Blokları Deneme Desenine göre üç tekerrürlü olarak kurulmuștur. Araștırmada incelenen; salkım çıkarma süresi, bin tane ağırlığı, bitki boyu, salkımda tane ağırlı̆ı, hektolitre ağırı̆̆ı, metrekarede salkım sayısı, protein miktarı, tane verimi, hasat indeksi ve yatma gibi tüm özellikler bakımından çeșitler arasında önemli farklılıklar elde edilmiștir. TokatKazova lokasyonunda en yüksek tane verimi Albatros (501.5 kg da-1) en düșük tane verimi BC Marta (211.3 $\mathrm{kg} \mathrm{da}^{-1}$ ) çeșidinden elde edilirken, Samsun-Havza lokasyonunda en yüksek tane verimi Sarı (436.9 kg da-1) en düșük tane verimi Haskara (214.8 $\left.\mathrm{kg} \mathrm{da}^{-1}\right)$ çeșidinden elde edilmiștir. Öte yandan, en yüksek tane protein oranı Tokat-Kazova lokasyonunda Kahraman (\%13.98), Samsun-Havza lokasyonunda Faikbey (\%14.12) çeșitlerinden elde edilmiștir. Elde edilen veriler doğrultusunda; Tokat-Kazova lokasyonunda Albatros, Samsun-Havza lokasyonunda Faikbey çeșitleri verim ve kalite bakımından öne çıkan çeșitler olmuștur.

Anahtar Kelimeler: Yulaf, çeșit, kalite, verim

\section{Determination of Yield and Quality Parameters of Some Oat Varieties (Avena sativa L.) in Different Locations}

\section{Abstract}

This study was carried out in the 2015-2016 vegetation period in order to determine the yield and quality parameters of some oat varieties in Tokat Kazova and Samsun Havza locations. A total of 15 oats (Avena sativa L.) cultivars were used as research material. The trial was established in three replications according to the Randomized Blocks Experimental Design. Significant differences were obtained between the varieties regarding all characteristics such as days to heading, thousand grain weight, plant height, weight of grain per panicle, hectoliter weight, the number of panicles per square meter, protein content, grain yield, harvest index and lodging. The lowest and the highest grain yield were obtained from BC Marta $\left(211.3 \mathrm{~kg} \mathrm{da}^{-1}\right)$ and Albatros $\left(501.5 \mathrm{~kg} \mathrm{da}^{-1}\right)$ varieties in the Tokat-Kazova location, whereas the highest grain yield and the lowest grain yield were obtained from Sari $\left(436.9 \mathrm{~kg} \mathrm{da}^{-1}\right)$ and Haskara $\left(214.8 \mathrm{~kg} \mathrm{da}^{-1}\right)$ varieties in Samsun-Havza location, respectively. On the other hand, the highest grain protein content was obtained from Kahraman (13.98\%) cultivar in Tokat-Kazova location and Faikbey (14.12\%) cultivar in Samsun-Havza location. According to the obtained data; Albatros in Tokat-Kazova location and Faikbey variety in SamsunHavza location became prominent in terms of yield and quality.

Keywords: Oat, variety, quality, yield

\section{Giriș}

$\begin{array}{lrr}\text { ulaf (Avena sativa } & \text { L.), } & \text { hayvan } \\ \text { beslenmesinin } & \text { yanı sıra insan }\end{array}$ beslenmesinde de önemi her geçen gün artan tahıl bitkisidir. Üretimi gerçekleștirilen kültür bitkilerinde 9.6 milyon hektar ekim alanı ve 22.7 milyon ton üretim miktarı ile yulaf dünyada tahıl cinsleri arasında 6. sırada yer almaktadır (Anonim, 2016a).
Ülkemizde 14 tescilli, 3 üretim izinli yulaf çeșidibulunmaktaolup, yaklașık994.4 bindekar alanda 225 bin ton üretime sahiptir. Yulafın, son beș yıllık ekiliș alanında yaklașık \%21'lik, üretim miktarında ise \%15'lik artıșlar görülmektedir (Anonim, 2016b). Ülkemizde ve dünyada insanların artan gelir seviyeleriyle birlikte gıda tüketimi ve beslenme alıșkanlıklarında 
meydana gelen değișikliklerden kaynaklı yulaf tüketimi ön plana çıkmaktadır. Yulafın önemli antioksidanlar içermesinin yanı sıra gluten enteropatisi olan insanların yulaf tüketimi sırasında düșük hassasiyet sağlaması ve protein miktarının yüksek olması önemini arttırmaktadır (Dumlupınar, 2010). Yüksek besin değerine sahip olması dolayısıyla hayvan beslenmesi sırasında süt verimini artırması ve hazmı kolaylaștırıcı etkisi de bilinmektedir. Bu bağlamda yulaf, tanelerindeki avenin (prolamin) proteinleri bulundurmasından dolayı genç hayvanların gelișmesinde önemli bir bitkidir. İnsan gıdası ya da hayvan beslenmesinde kullanılması gibi üreticinin talepleri doğrultusunda yulaf çeșitlerinden beklenti değișiklik gösterse de yüksek tane verimi istenen en önemli özelliklerden birisidir (Tamn, 2003; Sarı ve İmamoğlu, 2011). İnsan beslenmesinde; protein içeriği, tane verimi, bin tane ağırlığı ve hektolitre ağırlığı bakımından yüksek çeșit ıslahı, hayvan beslenmesinde ise protein miktarı ve sap verimi yüksek, uzun boylu çeșit ıslahı amaçlanmaktadır (Zutee ve Bulbyks, 1996).

Tokat ilinde yulafın (tane) 13 bin da alanda, 2.5 bin ton üretimi gerçekleștirilmekte olup, ortalama verim $170 \mathrm{~kg} \mathrm{da}^{-1}$ 'dır. Samsun' da ise, yaklașık 18 bin da ekim alanı, 3.5 bin ton üretim miktarı ve $193 \mathrm{~kg} \mathrm{da}{ }^{-1}$ verim mevcuttur (Anonim, 2016b). Yem ya da tane üretimi tercihlerine göre çeșit tavsiyesinde bulunmak açısından lokasyonlara adapte olmuș performansı yüksek yulaf çeșitlerinin belirlenmesi son derece önemlidir. Yapılan çalıșma ile, ülkemizdeki bazı tescilli ve üretim izinli çeșitlerin farklı lokasyonlardaki verim ve kalite kriterleri incelenip lokasyonlara uygun, performansı yüksek çeșitlerin belirlenmesi amaçlanmıștır.

\section{Materyal-Yöntem}

$\mathrm{Bu}$ araștırma, yulaf çeșitlerinin TokatKazova ve Samsun-Havza koșullarında 2015-2016 yetiștirme döneminde verim ve kalite özelliklerinin belirlenmesi amacıyla yürütülmüștür. Lokasyonlar, $40^{\circ}$ kuzey enlemleri ile $36^{\circ}$ doğu boylamları arasında yer almaktadır. Tokat-Kazova lokasyonunun denizden yüksekliği 608 m, Samsun-Havza lokasyonu ise, 675 m'dir. Araștırma materyalleri; 5 kamu kurulușu, 4 özel sektörden olmak üzere toplam 15 çeșitten olușmaktadır. Araștırmada Checota (Geçit Kușağı Tar. Arș. Ens.), Faikbey, Seydișehir, Yeniçeri (Bahri Dağdaș Tar. Arș. Ens.), Sebat (Trakya Tarım ve Vet Tic. Ltd. Ști.), Kırklar, Kahraman (Trakya Tar. Arș. Ens.), Sarı, Fetih, Haskara (Ege Tar. Arș. Ens.), Arslanbey (KSÜ Ziraat Fakültesi), Albatros (Ata Toh.), BC Marta (BC Institüte Tar. Ür. Oto San ve Tic. Ltd. Ști.), Kehlibar, Gökova (Som Un San. Tic. Ltd. Ști.) çeșitleri kullanılmıștır. Tokat-Kazova ve Samsun-Havza lokasyonlarında toprak, her iki lokasyonda da killi-tınlı, tuzsuz (sırasıyla; $\% 0.007-0.003$ ), hafif alkali (sırasıyla; $\mathrm{pH}=7.88$ 7.55), kireç içeriği (sırasıyla; \%6.1-5.1) ve organik madde miktarı (sırasıyla; \%1.24-1.39) düșük, fosfor içeriği gübre takviyesi intiyaçlı (3.22-2.01 kg da-1), potasyumlu gübrelemeye intiyaç duyulmayan (sırasıyla; 68.98-66.33 kg $\mathrm{da}^{-1}$ ) yapıdadır. Deneme alanlarının çok yılık ve denemelerin yapıldığı yıllara ait bazı iklim verileri Çizelge 1'de verilmiștir. Araștırma, Tesadüf Blokları Deneme Deseninde üç tekerrürlü olarak kurulmuștur. Deneme 2015 yılında Havza lokasyonunda 11 Kasım, Kazova lokasyonunda $1 \mathrm{Kasım}$ tarihinde $20 \mathrm{~cm}$ sıra arası mesafede el ile ekimi yapılmıș olup, ekim sıklığı m²'de 600 bitki olacak șekilde ayarlanmıștır (Peltonen-Sainiou ve ark. 1995). Her bir parsel 5 m uzunluğunda dört sıradan olușmuș ve aralarında boșluk bırakılmamıștır. Denemede her iki lokasyonda da dekara $12 \mathrm{~kg}$ $\mathrm{N}$ ve 6 kg $\mathrm{P}_{2} \mathrm{O}_{5}$ olacak șekilde gübre uygulanıp, azotun yarısı ve fosforun ise tamamı ekimle birlikte verilmiș olup, azotun geri kalan kısmı ise sapa kalkma dönemi öncesinde verilmiștir. Hasat, Havza lokasyonunda 15 Haziran, Kazova lokasyonunda 10 Haziran tarihinde parselin bașlarından 0.25 m'lik kısımlar kenar tesiri olarak atıldıktan sonra geri kalan $3.6 \mathrm{~m}^{2}$ lik alanda, tarımsal ölçüm ve gözlemler sırasıyla; Kün (1996) ve Dumlupınar (2010)'ın kullandığı yöntemler dikkate alınarak yapılmıștır. Yatma değerleri 1-9 arası Buerstmayr ve ark. (2007)'e göre skorlandırılmıștır. Protein miktarı Kjelhdahl yöntemiyle AACC Metot 46-10'a göre belirlenmiș, 5.83 faktörüne göre proteine dönüștürülmüștür (Anonim, 1986; AACC, 2000). 
Çizelge 1. Tokat-Kazova ve Samsun-Havza uzun yıllar ve deneme yılı iklim parametreleri*

Table 1. Tokat-Kazova and Samsun-Havza long years and trial year climate parameters

\begin{tabular}{ccccccccccc}
\hline \multirow{2}{*}{$\begin{array}{c}\text { İklim } \\
\text { Faktörleri* }\end{array}$} & \multirow{2}{*}{ Yıllar } & \multicolumn{8}{c}{ Aylar } & \multirow{2}{*}{ Top. /Ort. } \\
\cline { 3 - 9 } & Kasım & Aralık & Ocak & Șubat & Mart & Nisan & Mayıs & Haziran & \\
\hline \multirow{3}{*}{ Yağıș } & Samsun & 2.7 & 34.5 & 84.0 & 27.6 & 78.3 & 34.1 & 143.0 & 90.8 & 495.0 \\
$(\mathrm{~mm})$ & Uz. Yıllar & 55.1 & 57.1 & 38.0 & 33.4 & 31.3 & 50.6 & 62.6 & 65.6 & 393.7 \\
& Tokat & 15.8 & 35.5 & 104.6 & 42.6 & 49.4 & 23.4 & 89.5 & 33.1 & 393.9 \\
& Uz. Yıllar & 44.1 & 46.6 & 40.3 & 34.0 & 40.7 & 55.3 & 58.5 & 38.3 & 357.8 \\
\hline \multirow{2}{*}{ Ortalama } & Samsun & 8.3 & 0.8 & 1.0 & 6.9 & 7.8 & 12.4 & 13.5 & 18.7 & 8.68 \\
Sıcaklık & Uz. Yıllar & 6.2 & 2.5 & 0.9 & 1.4 & 5.0 & 10.1 & 13.4 & 17.0 & 7.06 \\
$\left({ }^{\circ} \mathrm{C}\right)$ & Tokat & 8.7 & 1.0 & 1.7 & 7.5 & 9.6 & 15.3 & 16.5 & 21.4 & 10.21 \\
& Uz. Yıllar & 7.9 & 3.9 & 1.8 & 3.5 & 7.4 & 12.5 & 16.5 & 19.9 & 9.18 \\
\hline
\end{tabular}

*; Meteoroloji Genel Müdürlüğü

\section{Bulgular-Tartıșma}

\section{Salkım Çıkarma Süresi}

Farklı lokasyonlarda incelenen bazı yulaf çeșitlerinin salkım çıkarma süresine ait ortalama değerleri Çizelge 2'de verilmiștir. Lokasyonlar arasındaki farkın \%1 düzeyinde önemli olduğu saptanmıștır. Salkım çıkarma süresi; Tokat-Kazova lokasyonunda 149.5 gün ile 173.3 gün, Samsun-Havza lokasyonunda 161.0 gün ile 184.8 gün arasında farklılık göstermiștir. Tokat-Kazova ve SamsunHavza lokasyonlarında çeșitler arasında önemli farklılıklar elde edilmiș olup, Haskara en uzun sürede salkım çıkaran çeșit olurken,
Sarı her iki lokasyonda da en erkenci çeșit özelliği göstermiștir (Çizelge 2). Yapılan farklı çalıșmalarda araștırıcılar yulaf bitkisinde salkım çıkarma süresinin 141 ile 185 gün arasında değiștiğini, çiçeklenme süresindeki farklılığın çeșitlerin genetik özelliklerinden kaynaklandığı bildirilmiștir (Nawaz et al., 2004; Locatelli et al., 2008; Dumlupınar ve ark., 2016).

\section{Bitki Boyu}

Bitki boyu bakımından yulaf çeșitlerinin lokasyon ortalamaları arasındaki farkın \%1 düzeyinde önemli olduğu bulunmuștur (Çizelge 2). Samsun-Havza lokasyonunda ortalama bitki boyu diğer lokasyona göre daha yüksektir

Çizelge 2. Tokat-Kazova ve Samsun-Havza lokasyonlarında bazı yulaf çeșitlerinin salkım çıkarma süresi (gün) ve bitki boyu (cm) değerleri

Table 2. The days to heading (day) and plant height $(\mathrm{cm})$ values of some oat varieties in Tokat-Kazova and Samsun-Havza locations

\begin{tabular}{|c|c|c|c|c|c|c|c|c|c|c|c|c|}
\hline \multirow{3}{*}{$\begin{array}{l}\text { Çeșitler } \\
\text { Faikbey }\end{array}$} & \multicolumn{6}{|c|}{ Salkım Çıkarma Süresi (gün) } & \multicolumn{6}{|c|}{ Bitki Boyu (cm) } \\
\hline & \multicolumn{2}{|c|}{ Tokat } & \multicolumn{2}{|c|}{ Samsun } & \multicolumn{2}{|c|}{ Ortalama } & \multicolumn{2}{|c|}{ Tokat } & \multicolumn{2}{|c|}{ Samsun } & \multicolumn{2}{|c|}{ Ortalama } \\
\hline & 153.8 & $e^{\star \star}$ & 165.3 & $e^{\star \star *}$ & 159.5 & $d e^{\star *}$ & 123.9 & $a^{\star \star}$ & 129.4 & $a b^{\star \star}$ & 126.7 & $a b^{\star *}$ \\
\hline Bc Marta & 165.3 & $\mathrm{bc}$ & 176.8 & $\mathrm{C}$ & 171.0 & $a b c$ & 103.8 & cde & 110.8 & d & 107.3 & $\mathrm{bc}$ \\
\hline Fetih & 162.3 & bc & 173.8 & C & 168.0 & bc & 83.0 & $f$ & 82.6 & g & 82.8 & $f$ \\
\hline Haskara & 173.3 & $\mathrm{a}$ & 184.8 & $\mathrm{a}$ & 179.0 & a & 122.1 & $a b$ & 137.8 & $\mathrm{a}$ & 130.0 & a \\
\hline Sebat & 163.5 & $\mathrm{~cd}$ & 172.0 & $\mathrm{~cd}$ & 166.3 & $c d$ & 112.4 & bcd & 120.6 & $\mathrm{bc}$ & 116.5 & $\mathrm{~b}$ \\
\hline Arslanbey & 165.5 & $\mathrm{bc}$ & 177.0 & $\mathrm{C}$ & 171.3 & $a b c$ & 96.4 & e & 98.4 & $f$ & 97.4 & de \\
\hline Albatros & 165.3 & $\mathrm{bc}$ & 176.8 & $\mathrm{C}$ & 171.0 & $a b c$ & 104.8 & cde & 113.8 & $\mathrm{~cd}$ & 109.3 & $\mathrm{bc}$ \\
\hline Kahraman & 156.8 & de & 168.3 & de & 162.5 & cde & 99.9 & e & 105.6 & def & 102.8 & cde \\
\hline Kırklar & 163.5 & $\mathrm{bc}$ & 175.0 & $\mathrm{C}$ & 169.3 & $a b c$ & 103.5 & cde & 99.7 & $f$ & 101.6 & cde \\
\hline Sarı & 149.5 & $f$ & 161.0 & $f$ & 155.3 & e & 105.2 & cde & 106.4 & def & 105.8 & bcd \\
\hline Seydișehir & 166.3 & $\mathrm{~b}$ & 177.8 & $\mathrm{bc}$ & 172.0 & $a b c$ & 114.4 & cde & 126.4 & $a b$ & 120.4 & $a b$ \\
\hline Yeniçeri & 164.5 & $\mathrm{bc}$ & 166.0 & $\mathrm{C}$ & 170.3 & $a b c$ & 104.4 & cde & 104.7 & def & 104.6 & bcd \\
\hline Checota & 171.3 & $\mathrm{a}$ & 182.8 & $a b$ & 177.0 & $a b$ & 117.2 & $a b$ & 125.6 & $a b$ & 121.4 & $a b$ \\
\hline Gökova & 163.0 & $\mathrm{bc}$ & 174.5 & $\mathrm{C}$ & 168.8 & bcd & 117.9 & $a b$ & 122.4 & bc & 120.2 & $a b$ \\
\hline Kehlibar & 163.8 & $\mathrm{bc}$ & 175.3 & $\mathrm{C}$ & 169.5 & $\mathrm{abc}$ & 101.9 & d & 101.4 & ef & 101.7 & cde \\
\hline Ort. & \multicolumn{2}{|c|}{$163.2 \mathrm{~b}$} & \multicolumn{2}{|c|}{$173.8 a^{*}$} & \multicolumn{2}{|c|}{168.7} & \multicolumn{2}{|c|}{$107.4 \mathrm{~b}$} & \multicolumn{2}{|c|}{$112.4 \mathrm{a}^{\star \star}$} & \multicolumn{2}{|c|}{109.9} \\
\hline V. K. & \multicolumn{2}{|c|}{1.70} & \multicolumn{2}{|c|}{1.93} & \multicolumn{2}{|c|}{2.21} & \multicolumn{2}{|c|}{5.91} & \multicolumn{2}{|c|}{6.42} & \multicolumn{2}{|c|}{7.60} \\
\hline
\end{tabular}

*, **; \%5, \%1 önem seviyesindedir. 
(Çizelge 2). En yüksek bitki boyu Tokat-Kazova lokasyonunda Faikbey $(123.9 \mathrm{~cm})$, SamsunHavza'da Haskara $(137.8 \mathrm{~cm})$ çeșitlerinden elde edilmiștir. Her iki lokasyonda çeșitler arasındaki fark \%1 düzeyinde önemli olup, Fetih en düșük bitki boyuna sahiptir (Çizelge 2). Araștıııılar bitki boyunun çevresel faktörlerin yanı sıra genetik yapıdan da etkilendiğini, kısa boyluluk ve yatmaya dayanıklıı̆ın yulafta hasat kolaylığı sağlaması açısından istenilen özellik olduğunu belirtmișlerdir (Kara ve ark., 2007; Buerstmayr ve ark., 2007; Sarı ve ark., 2012). Dumlupınar (2010) farklı yulaf genotipleriyle yaptığı çalıșmada bitki boyunun 93.6 ile 158.2 $\mathrm{cm}$ arasında değiștiğini bildirmiștir.

\section{Bin Tane Ağırlığı}

Araștırmada bin tane ağırlıkları bakımından her iki lokasyonda da çeșitler arasındaki fark \%1 düzeyinde önemlidir (Çizelge 3). Çeșitlerin ortalama bin tane ağırlık değerleri TokatKazova lokasyonunda $34.1 \mathrm{~g}$, Samsun-Havza lokasyonunda $36.1 \mathrm{~g}$ arasında değișiklik göstermiș, lokasyonlar arasındaki fark da önemli bulunmuștur (Çizelge 3). Çizelge 3'te görüldüğü üzere Tokat-Kazova ve SamsunHavza lokasyon ortalamalarında sırasıyla; Kırklar ve Sarı en yüksek, Sebat ve Seydișehir çeșitleri en düșük bin tane ağırlıklarına sahiptir. Yulaf genotiplerinde ortalama bin tane ağırlıkların $16.81 \mathrm{~g}$ ile $50.60 \mathrm{~g}$ arasında değiștiği bildirilmiștir (Dumlupınar, 2010; Sarı ve İmamoğlu, 2011; Narlıoğlu, 2016).

\section{Metrekarede Salkım Sayısı}

Metrekarede salkım sayısı bakımından her iki lokasyonda da çeșitler ile ortalamalar arasındaki fark \%1 düzeyinde önemli bulunmuștur (Çizelge 3). Tokat-Kazova lokasyonunda Kırklar, Samsun-Havza lokasyonunda Bc Marta çeșitleri en yüksek metrekarede salkım sayısı vermișlerdir. Her iki lokasyon ortalamasına göre, Kırklar çeșidi en fazla metrekarede salkım sayısına sahiptir (Çizelge 3). Araștıııcılar, yulaf bitkisinin çimlenme yüzdesinin düșük olmasından dolayı az tohum kullanıldığında kardeșlenme oranının artacağını, kardeș bitkilerin verime etkisinin düșük olacağını bu sebeple ekim sıklığının 600 bitki/m² olması gerektiği bildirilmiștir (PeltonenSainio et al., 1995). Farklı araștırmalarda ortalama metrekarede salkım sayısı 345.6 ile 836.0 adet arasında değișmiș (Yılmaz, 1996; Dumlupınar, 2010), çeșitler arasındaki farkın ise önemli olduğu bildirilmiștir (Maral, 2009).

Çizelge 3. Tokat-Kazova ve Samsun-Havza lokasyonlarında bazı yulaf çeșitlerinin bin tane ağırlığı (g) ve metrekarede salkım sayısı (adet) değerleri

Table 3. The values of some oat varieties in Tokat-Kazova and Samsun-Havza locations are thousand grain weight $(g)$ and the number of panicles per square meter (number)

\begin{tabular}{|c|c|c|c|c|c|c|c|c|c|c|c|c|}
\hline \multirow{3}{*}{$\begin{array}{l}\text { Çeșitler } \\
\text { Faikbey }\end{array}$} & \multicolumn{6}{|c|}{ Bin Tane Ağırlığı (g) } & \multicolumn{6}{|c|}{ Metrekarede Salkım Sayısı (adet) } \\
\hline & \multicolumn{2}{|c|}{ Tokat } & \multicolumn{2}{|c|}{ Samsun } & \multicolumn{2}{|c|}{ Ortalama } & \multicolumn{2}{|c|}{ Tokat } & \multicolumn{2}{|c|}{ Samsun } & \multicolumn{2}{|c|}{ Ortalama } \\
\hline & 33.0 & $\operatorname{cde}^{\star \star}$ & 32.7 & $d-g^{\star \star}$ & 32.8 & def $^{\star \star}$ & 590.3 & $\mathrm{bc}^{\star \star}$ & 591.1 & $a b^{\star \star}$ & 590.7 & $\mathrm{~b}^{\star \star}$ \\
\hline Bc Marta & 36.7 & $a b c$ & 41.1 & a & 38.9 & $a b$ & 602.8 & bc & 628.6 & a & 615.7 & $a b$ \\
\hline Fetih & 29.2 & def & 33.5 & def & 31.4 & def & 601.8 & $\mathrm{bc}$ & 569.0 & $a b$ & 585.4 & bc \\
\hline Haskara & 29.3 & def & 41.2 & a & 35.1 & $\mathrm{~cd}$ & 591.8 & bc & 543.4 & $\mathrm{~b}$ & 567.6 & c \\
\hline Sebat & 27.6 & f & 32.1 & efg & 29.8 & g & 619.3 & $\mathrm{bc}$ & 569.9 & $a b$ & 594.6 & b \\
\hline Arslanbey & 37.5 & $a b c$ & 32.8 & $d-g$ & 35.1 & $\mathrm{~cd}$ & 585.3 & $c$ & 571.2 & $a b$ & 578.3 & bc \\
\hline Albatros & 28.6 & ef & 34.3 & cde & 31.4 & def & 590.5 & $\mathrm{bc}$ & 604.3 & $a b$ & 597.4 & $b$ \\
\hline Kahraman & 38.3 & $\mathrm{a}$ & 34.5 & $c d$ & 36.4 & bc & 586.5 & c & 624.0 & $\mathrm{a}$ & 605.3 & $a b$ \\
\hline Kırklar & 41.2 & $a$ & 40.7 & $a$ & 40.9 & $a$ & 680.2 & $a$ & 613.3 & $a$ & 646.8 & $a$ \\
\hline Sarı & 40.9 & $a$ & 42.1 & $a$ & 41.5 & $a$ & 588.3 & c & 591.3 & $a b$ & 589.8 & $b$ \\
\hline Seydișehir & 28.9 & def & 30.8 & $g$ & 29.8 & g & 598.8 & $\mathrm{bc}$ & 613.8 & $a$ & 606.3 & $a b$ \\
\hline Yeniçeri & 28.4 & ef & 31.7 & $\mathrm{fg}$ & 30.0 & g & 634.0 & $b$ & 569.8 & $a b$ & 601.9 & $a b$ \\
\hline Checota & 37.9 & $a b$ & 38.4 & $b$ & 38.1 & $a b$ & 590.3 & $\mathrm{bc}$ & 616.5 & a & 603.4 & $a b$ \\
\hline Gökova & 39.8 & $\mathrm{a}$ & 40.2 & $a b$ & 40.0 & $a b$ & 619.8 & $\mathrm{bc}$ & 615.2 & $\mathrm{a}$ & 617.5 & $a b$ \\
\hline Kehlibar & 33.4 & bcd & 36.0 & $c$ & 34.7 & $\mathrm{~cd}$ & 597.3 & $\mathrm{bc}$ & 609.3 & $a b$ & 603.3 & $a b$ \\
\hline Ort. & \multicolumn{2}{|c|}{$34.1 \mathrm{~b}$} & \multicolumn{2}{|c|}{$36.1 \mathrm{a}^{\star \star}$} & \multicolumn{2}{|c|}{35.1} & \multicolumn{2}{|c|}{$607.3 a^{\star \star}$} & \multicolumn{2}{|c|}{$595.4 \mathrm{~b}$} & \multicolumn{2}{|c|}{600.3} \\
\hline V. K. & \multicolumn{2}{|c|}{6.89} & \multicolumn{2}{|c|}{7.11} & \multicolumn{2}{|c|}{7.74} & \multicolumn{2}{|c|}{9.32} & \multicolumn{2}{|c|}{8.86} & \multicolumn{2}{|c|}{10.78} \\
\hline
\end{tabular}

**; \%1 önem seviyesindedir. 


\section{Salkımda Tane Ağırı̆̆ı}

Salkımda tane ağırlığı bakımından lokasyonlarda çeșitler arasında \%1 düzeyinde önemli farklılıklar görülmüștür (Çizelge 4). Tokat-Kazova lokasyonunda Albatros (3.12 g) çeșidi en fazla, Bc Marta (1.47 g) en az salkımda tane ağırlığına sahiptir. Kehlibar (2.18 g), Sarı (2.77 g), Kırklar (2.21 g) ve Faikbey $(2.23 \mathrm{~g})$ çeșitleri ise ortalamanın üzerindedir (Çizelge 4). Samsun-Havza'da en yüksek değer Sebat $(2.88 \mathrm{~g})$ çeșidinden elde edilmiș olup, Sarı $(2.74 \mathrm{~g})$ ve Kehlibar (2.75 g) çeșitleri de yüksek grupta yer almaktadırlar. Haskara $(1.81 \mathrm{~g})$ çeșidi ise en düșük değere sahip olup, Seydișehir (1.89 g) çeșidi de aynı gruptadır (Çizelge 4). Farkı yulaf genotipleri ile yapılan çalıșmalarda araștıııcılar salkımda tane ağırlığının $0.35 \mathrm{~g}$ ile $6.60 \mathrm{~g}$ arasında değiștiğini bildirmișlerdir (Mut ve ark., 2011; Dumlupınar ve ark., 2017). Ortalama salkımda tane ağırlığı Tokat-Kazova'da 2.06 g, Samsun-Havza'da ise, $2.31 \mathrm{~g}$ olarak bulunmuștur. Lokasyonlar arasındaki fark \%1 düzeyinde önemlidir.

\section{Hektolitre Ağırı̆̆ı}

Hektolitre ağırlığı bakımından çeșitler arasındaki fark her iki lokasyonda da \%1 düzeyinde önemlidir (Çizelge 4). SamsunHavza ve Tokat-Kazova lokasyonlarında en yüksek hektolitre ağırlı̆ına sahip çeșitler sırasıyla; Gökova (52.9 kg hl-1) ve Haskara $\left(54.4 \mathrm{~kg} \mathrm{hl}^{-1}\right)$ çeșitleridir. Arslanbey (sırasıyla; $43.3 \mathrm{~kg} \mathrm{hl}^{-1}, 44.4 \mathrm{~kg} \mathrm{hl}^{-1}$ ) çeșidi her iki lokasyonda da en düșük hektolitre ağırığındadır (Çizelge 4). Yapılan bașka bir çalıșmada da hektolitre ağırlığı bakımından çeșitler arasındaki fark önemli bulunmuștur (İnan ve ark., 2005). Ortalama hektolitre ağırlıkları Tokat-Kazova lokasyonunda $51.4 \mathrm{~kg} \mathrm{hl}^{-1}$, Samsun-Havza lokasyonunda $49.7 \mathrm{~kg} \mathrm{hl}^{-1}$ olarak saptanmıș, lokasyonlar arasındaki fark \%1 düzeyinde önemli bulunmuștur. Ortalama hektolitre ağırlıklarının çeșitlerde $49.2 \mathrm{~kg} \mathrm{hl}^{-1}$ ile $52.4 \mathrm{~kg}$ $\mathrm{hl}^{-1}$ arasında değiștiği yapılan çalıșmalarda belirlenmiștir (Sarı ve ark., 2012).

\section{Tane Verimi}

Tane verimi bakımından yulaf çeșitleri arasında \%1 düzeyinde önemli farklllıklar elde edilmiștir (Çizelge 5). Tokat-Kazova lokasyonunda Albatros çeșidi en yüksek tane verimine sahip olup, Faikbey çeșidi de onu takip etmektedir (Çizelge 5).

Çizelge 4. Tokat-Kazova ve Samsun-Havza lokasyonlarında bazı yulaf çeșitlerinin salkımda tane ağırlığı (g) ve hektolitre ağırlığı $\left(\mathrm{kg} \mathrm{hl}^{-1}\right)$ değerleri

Table 4. The weight of grain per panicle $(\mathrm{g})$ and hectolitre weight $\left(\mathrm{kg} \mathrm{hl}^{-1}\right)$ values of some oat varieties in Tokat-Kazova and Samsun-Havza locations.

\begin{tabular}{|c|c|c|c|c|c|c|c|c|c|c|c|c|}
\hline \multirow{3}{*}{$\begin{array}{l}\text { Çeșitler } \\
\text { Faikbey }\end{array}$} & \multicolumn{6}{|c|}{ Salkım Tane Ağırlığı (g) } & \multicolumn{6}{|c|}{ Hektolitre Ağırlığı $\left(\mathrm{kg} \mathrm{hl}^{-1}\right)$} \\
\hline & \multicolumn{2}{|c|}{ Tokat } & \multicolumn{2}{|c|}{ Samsun } & \multicolumn{2}{|c|}{ Ortalama } & \multicolumn{2}{|c|}{ Tokat } & \multicolumn{2}{|c|}{ Samsun } & \multicolumn{2}{|c|}{ Ortalama } \\
\hline & 2.23 & $\mathrm{C}^{\star \star}$ & 2.35 & $\mathrm{~b}^{\star \star}$ & 2.29 & $\mathrm{bc}^{\star \star}$ & 46.5 & $\mathrm{C}^{\star \star}$ & 45.9 & $e^{\star \star}$ & 46.2 & $\mathrm{~cd}^{\star \star}$ \\
\hline Bc Marta & 1.47 & e & 2.02 & $\mathrm{~cd}$ & 1.75 & f & 52.3 & $a b$ & 50.9 & $a-d$ & 51.6 & $a b c$ \\
\hline Fetih & 1.50 & de & 2.03 & $\mathrm{~cd}$ & 1.77 & $f$ & 53.8 & a & 52.5 & $a b$ & 53.2 & a \\
\hline Haskara & 1.87 & cde & 1.81 & e & 1.84 & e & 54.4 & a & 50.7 & $a-d$ & 52.6 & $a b$ \\
\hline Sebat & 2.09 & c & 2.88 & $a$ & 2.49 & $b$ & 52.3 & $a b$ & 48.6 & $\mathrm{~cd}$ & 50.5 & $\mathrm{bc}$ \\
\hline Arslanbey & 1.77 & cde & 2.22 & $\mathrm{bc}$ & 2.00 & $d$ & 44.4 & $\mathrm{c}$ & 43.3 & $f$ & 43.9 & d \\
\hline Albatros & 3.12 & $\mathrm{a}$ & 2.53 & $b$ & 2.83 & $\mathrm{a}$ & 52.9 & $a b$ & 52.2 & $a b c$ & 52.6 & $a b$ \\
\hline Kahraman & 1.98 & $c d$ & 2.25 & $\mathrm{bc}$ & 2.12 & $c d$ & 53.8 & $\mathrm{a}$ & 51.7 & $a b c$ & 52.8 & $a b$ \\
\hline Kırklar & 2.21 & $c$ & 2.44 & $b$ & 2.31 & bc & 52.3 & $a b$ & 49.3 & $a-e$ & 50.8 & $\mathrm{bc}$ \\
\hline Sarı & 2.77 & $b$ & 2.74 & a & 2.76 & $\mathrm{a}$ & 49.9 & $b$ & 47.8 & de & 48.9 & $c$ \\
\hline Seydișehir & 1.88 & cde & 1.89 & e & 1.89 & e & 50.4 & $b$ & 49.5 & $a-d$ & 50.0 & bc \\
\hline Yeniçeri & 2.04 & $\mathrm{~cd}$ & 2.12 & $c d$ & 2.08 & $c d$ & 51.5 & $a b$ & 50.9 & $a-d$ & 51.2 & $a b c$ \\
\hline Checota & 2.03 & $\mathrm{~cd}$ & 2.38 & b & 2.21 & bcd & 51.2 & $a b$ & 49.1 & $b-e$ & 50.2 & $\mathrm{bc}$ \\
\hline Gökova & 1.79 & cde & 2.31 & $b$ & 2.05 & $\mathrm{~cd}$ & 53.7 & a & 52.9 & a & 53.3 & a \\
\hline Kehlibar & 2.18 & c & 2.75 & $\mathrm{a}$ & 2.47 & $\mathrm{~b}$ & 51.7 & $a b$ & 50.4 & $a-d$ & 51.1 & $a b c$ \\
\hline Ort. & \multicolumn{2}{|c|}{$2.06 \mathrm{~b}$} & \multicolumn{2}{|c|}{$2.31 \mathrm{a}^{\star \star}$} & \multicolumn{2}{|c|}{2.19} & \multicolumn{2}{|c|}{$51.4 a^{\star \star}$} & \multicolumn{2}{|c|}{$49.7 \mathrm{~b}$} & \multicolumn{2}{|c|}{50.6} \\
\hline V. K. & \multicolumn{2}{|c|}{8.92} & \multicolumn{2}{|c|}{7.26} & \multicolumn{2}{|c|}{9.49} & \multicolumn{2}{|c|}{5.37} & \multicolumn{2}{|c|}{6.81} & \multicolumn{2}{|c|}{7.94} \\
\hline
\end{tabular}


Samsun-Havza lokasyonunda ise, en yüksek tane verimi Sarı çeșidinden elde edilmiș, Faikbey, Sebat, Albatros, Kırklar çeșitleri de onu takip etmiștir. Her iki lokasyon incelendiğinde tane verimleri $211.3 \mathrm{~kg} \mathrm{da}^{-1}$ ile $501.5 \mathrm{~kg} \mathrm{da}^{-1}$ arasında değișmiș, lokasyonlar arasındaki fark \%1 seviyesinde önemli bulunmuștur (Çizelge 5). Konu ile ilgili çalıșmalarda araștıııılar tane veriminde çeșitler arasındaki farkın önemli olduğunu, çeșitli özelliklerin tane verimine etki ettiğini (Sarı ve ark., 2012; Güngör ve ark., 2017), tane verimlerinin $118.0 \mathrm{~kg} \mathrm{da}^{-1}$ ile $650.2 \mathrm{~kg} \mathrm{da}^{-1}$ arasında farkllık gösterdiğini bildirmișlerdir (lannucci et al., 2011; Kahraman ve ark., 2012; Dumlupınar ve ark., 2016; Narlıŏlu, 2016).

\section{Protein Miktarı}

Kalite kriterleri açısından önemli bir parametre olan protein miktarında çeșitler arasındaki fark Tokat-Kazova lokasyonunda $\% 5$, Samsun-Havza lokasyonunda \%1 düzeyinde önemli bulunmuștur (Çizelge 5). Tokat-Kazova lokasyonunda Kahraman (\%13.98) diğer çeșitlere göre yüksek protein miktarıla ön plana çıkarken, Samsun-Havza lokasyonunda Faikbey (\%14.12) çeșidi en yüksek protein miktarına sahip olmuștur (Çizelge 5). Tokat-
Kazova ve Samsun-Havza lokasyonlarında sırasıyla; Faikbey (\%12.12) ve Checota (\%10.12) çeșitlerinden en düșük değerler elde edilmiștir (Çizelge 5). Lokasyonlar arasındaki fark da \%1 düzeyinde önemli bulunmuștur.

Yapılan çalıșmalarda yulaf çeșitlerinde protein miktarl; \%7.6 ile \%22.2 arasında değișiklik gösterdiği belirlenmiștir (Hischke et al., 1968; Sarı ve ark., 2012).

\section{Hasat Indeksi}

Araștırmada lokasyonlarda çeșitler arasında \%1 düzeyinde önemli farkllıklar bulunmuștur (Çizelge 6). Her iki lokasyonda da Albatros ve Sarı çeșitleri en yüksek hasat indeksi değerleri göstermiștir (Çizelge 6). Kazova ve Havza lokasyonlarında; Bc Marta, Haskara ve Seydișehir çeșitleri en düșük değerleri vermiș olup, lokasyon ortalamaları arasındaki fark \%1 düzeyinde önemli bulunmuștur (Çizelge 6). Islahçılar tarafından hasat indeksi parametresinin yüksek olması istenen bir özelliktir. Yapılan çalıșmalarda araștırıcılar yulaf genotiplerinin \%5.1-\%46.5 arasında hasat indeksi değerlerine sahip olduğunu bildirmișlerdir (lanucci et al., 2011; Sabandüzen ve Akçura, 2017).

Çizelge 5. Tokat-Kazova ve Samsun-Havza lokasyonlarında bazı yulaf çeșitlerinin tane verimi $\left(\mathrm{kg} \mathrm{da}^{-1}\right)$ ve protein miktarı (\%) değerleri

Table 5. The grain yield $\left(\mathrm{kg} \mathrm{da}^{-1}\right)$ and protein content (\%) values of some oat varieties in Tokat-Kazova and Samsun-Havza locations.

\begin{tabular}{|c|c|c|c|c|c|c|c|c|c|c|c|c|}
\hline \multirow{3}{*}{$\begin{array}{l}\text { Çeșitler } \\
\text { Faikbey }\end{array}$} & \multicolumn{6}{|c|}{ Tane Verimi $\left(\mathrm{kg} \mathrm{da}^{-1}\right)$} & \multicolumn{6}{|c|}{ Protein Miktarı (\%) } \\
\hline & \multicolumn{2}{|c|}{ Tokat } & \multicolumn{2}{|c|}{ Samsun } & \multicolumn{2}{|c|}{ Ortalama } & \multicolumn{2}{|c|}{ Tokat } & \multicolumn{2}{|c|}{ Samsun } & \multicolumn{2}{|c|}{ Ortalama } \\
\hline & 482.3 & $a b^{\star \star}$ & 354.4 & $a-d^{\star \star}$ & 418.4 & $a^{\star \star}$ & 12.12 & $\mathrm{C}^{*}$ & 14.12 & $a^{\star \star}$ & 13.12 & $a b^{*}$ \\
\hline Bc Marta & 211.3 & $\mathrm{~h}$ & 289.8 & $b-e$ & 250.6 & de & 12.72 & $a b c$ & 13.95 & $a b$ & 13.34 & $\mathrm{a}$ \\
\hline Fetih & 232.5 & gh & 234.6 & ef & 233.6 & e & 13.05 & $a b c$ & 13.11 & bc & 13.08 & $a b$ \\
\hline Haskara & 254.8 & fg & 214.8 & $f$ & 234.8 & e & 12.24 & $\mathrm{bc}$ & 12.34 & $\mathrm{~cd}$ & 12.29 & $\mathrm{bc}$ \\
\hline Sebat & 322.8 & e & 373.7 & $a-c$ & 348.3 & bc & 13.18 & $a b c$ & 12.58 & $\mathrm{~cd}$ & 12.88 & $a b c$ \\
\hline Arslanbey & 275.1 & $f$ & 250.4 & de & 262.8 & d & 13.65 & a & 13.01 & bc & 13.33 & a \\
\hline Albatros & 501.5 & a & 361.3 & $a-d$ & 431.4 & a & 12.28 & bc & 12.64 & c & 12.46 & $\mathrm{bc}$ \\
\hline Kahraman & 336.3 & de & 280.3 & $b-e$ & 308.3 & $c$ & 13.98 & $\mathrm{a}$ & 12.49 & $\mathrm{~cd}$ & 13.23 & $a b$ \\
\hline Kırklar & 445.5 & $b$ & 381.6 & $a b$ & 413.6 & $a b$ & 13.43 & $a b c$ & 10.52 & e & 11.97 & $\mathrm{bc}$ \\
\hline Sarı & 459.3 & $b$ & 436.9 & a & 448.1 & a & 13.05 & $a b c$ & 11.56 & $d$ & 12.30 & $\mathrm{bc}$ \\
\hline Seydișehir & 266.3 & $\mathrm{fg}$ & 256.1 & $c-e$ & 261.2 & $d$ & 13.49 & $a b$ & 10.56 & e & 12.02 & $\mathrm{bc}$ \\
\hline Yeniçeri & 342.8 & de & 285.7 & $b-e$ & 314.3 & c & 12.87 & $a b c$ & 12.35 & $\mathrm{~cd}$ & 12.61 & $\mathrm{bc}$ \\
\hline Checota & 400.4 & c & 322.9 & $b-e$ & 361.7 & bc & 13.33 & $a b c$ & 10.12 & e & 11.71 & c \\
\hline Gökova & 371.1 & $\mathrm{~cd}$ & 292.6 & b-e & 331.9 & bc & 13.82 & a & 12.38 & $\mathrm{~cd}$ & 13.10 & $a b$ \\
\hline Kehlibar & 394.9 & $\mathrm{C}$ & 315.8 & $b-e$ & 355.4 & $\mathrm{bc}$ & 12.28 & $\mathrm{bc}$ & 12.50 & $\mathrm{~cd}$ & 12.39 & $\mathrm{bc}$ \\
\hline Ort. & \multicolumn{2}{|c|}{$353.1 \mathrm{a}^{\star \star}$} & \multicolumn{2}{|c|}{$310.1 \mathrm{~b}$} & \multicolumn{2}{|c|}{331.6} & \multicolumn{2}{|c|}{$13.03 a^{\star \star}$} & \multicolumn{2}{|c|}{$12.28 \mathrm{~b}$} & \multicolumn{2}{|c|}{12.66} \\
\hline V. K. & \multicolumn{2}{|c|}{7.74} & \multicolumn{2}{|c|}{9.82} & \multicolumn{2}{|c|}{8.41} & \multicolumn{2}{|c|}{7.62} & \multicolumn{2}{|c|}{6.47} & \multicolumn{2}{|c|}{8.24} \\
\hline
\end{tabular}

*, **; \%5, \%1 önem seviyesindedir. 
Çizelge 6. Tokat-Kazova ve Samsun-Havza lokasyonlarında bazı yulaf çeșitlerinin hasat indeksi (\%) ve yatma (\%) değerleri

Table 6. The harvest index (\%) and lodging (\%) values of some oat varieties in Tokat-Kazova and Samsun-Havza locations.

\begin{tabular}{|c|c|c|c|c|c|c|c|c|c|c|c|c|}
\hline \multirow{3}{*}{$\begin{array}{l}\text { Çeșitler } \\
\text { Faikbey }\end{array}$} & \multicolumn{6}{|c|}{ Hasat İndeksi (\%) } & \multicolumn{6}{|c|}{ Yatma } \\
\hline & \multicolumn{2}{|c|}{ Tokat } & \multicolumn{2}{|c|}{ Samsun } & \multicolumn{2}{|c|}{ Ortalama } & \multicolumn{2}{|c|}{ Tokat } & \multicolumn{2}{|c|}{ Samsun } & \multicolumn{2}{|c|}{ Ortalama } \\
\hline & 20.4 & $\mathrm{bc}^{\star \star}$ & 16.7 & $\mathrm{~cd}^{\star \star}$ & 18.6 & $\mathrm{C}^{\star \star}$ & 1.33 & $\mathrm{C}^{*}$ & 3.00 & $b^{*}$ & 2.17 & $\mathrm{bc}^{*}$ \\
\hline Bc Marta & 11.9 & d & 17.9 & $\mathrm{~cd}$ & 14.9 & d & 3.33 & $b$ & 3.33 & $\mathrm{~b}$ & 3.33 & $\mathrm{~b}$ \\
\hline Fetih & 20.0 & $\mathrm{bc}$ & 20.6 & $\mathrm{C}$ & 20.3 & $\mathrm{bc}$ & 1.66 & $\mathrm{C}$ & 1.33 & $\mathrm{C}$ & 1.50 & $\mathrm{C}$ \\
\hline Haskara & 14.9 & $\mathrm{~d}$ & 13.9 & d & 14.4 & $d$ & 3.00 & $b$ & 7.66 & $\mathrm{a}$ & 5.33 & $a b$ \\
\hline Sebat & 22.7 & bc & 27.5 & $\mathrm{~b}$ & 25.1 & $b$ & 1.33 & C & 1.33 & $\mathrm{C}$ & 1.33 & $\mathrm{C}$ \\
\hline Arslanbey & 27.5 & $a b$ & 19.7 & $\mathrm{C}$ & 23.6 & $b$ & 1.33 & $\mathrm{C}$ & 3.00 & $b$ & 2.17 & bc \\
\hline Albatros & 35.8 & $\mathrm{a}$ & 33.5 & $\mathrm{a}$ & 34.7 & $\mathrm{a}$ & 1.00 & $\mathrm{C}$ & 1.33 & C & 1.50 & $\mathrm{C}$ \\
\hline Kahraman & 33.2 & $\mathrm{a}$ & 23.8 & bc & 28.5 & $a b$ & 1.66 & c & 1.33 & $\mathrm{C}$ & 1.50 & $\mathrm{C}$ \\
\hline Kırklar & 27.1 & $a b$ & 20.3 & C & 23.7 & $\mathrm{~b}$ & 1.00 & C & 1.66 & C & 1.50 & C \\
\hline Sarı & 34.2 & $\mathrm{a}$ & 29.0 & $a b$ & 31.6 & $\mathrm{a}$ & 1.00 & C & 1.00 & C & 1.17 & $\mathrm{C}$ \\
\hline Seydișehir & 13.8 & $\mathrm{~d}$ & 15.9 & $\mathrm{~d}$ & 14.9 & $\mathrm{~d}$ & 5.66 & $\mathrm{a}$ & 7.33 & a & 6.50 & $\mathrm{a}$ \\
\hline Yeniçeri & 22.6 & $\mathrm{bc}$ & 20.0 & $\mathrm{C}$ & 21.3 & $\mathrm{bc}$ & 1.33 & C & 3.33 & $b$ & 2.33 & $\mathrm{bc}$ \\
\hline Checota & 19.2 & bc & 17.8 & cd & 18.5 & C & 1.66 & $\mathrm{C}$ & 5.33 & $a b$ & 3.50 & $b$ \\
\hline Gökova & 25.5 & $a b$ & 21.7 & C & 23.6 & $b$ & 1.33 & $\mathrm{C}$ & 1.00 & C & 1.17 & $\mathrm{C}$ \\
\hline Kehlibar & 25.7 & $a b$ & 20.3 & $\mathrm{C}$ & 23.0 & $\mathrm{~b}$ & 1.33 & $\mathrm{C}$ & 1.33 & $\mathrm{C}$ & 1.50 & $\mathrm{C}$ \\
\hline Ort. & \multicolumn{2}{|c|}{$23.6 \mathrm{a}^{\star \star}$} & \multicolumn{2}{|c|}{$21.2 \mathrm{~b}$} & \multicolumn{2}{|c|}{22.4} & \multicolumn{2}{|c|}{1.86} & \multicolumn{2}{|c|}{2.89} & \multicolumn{2}{|c|}{2.43} \\
\hline V.K. & \multicolumn{2}{|c|}{9.28} & \multicolumn{2}{|c|}{8.56} & \multicolumn{2}{|c|}{9.41} & \multicolumn{2}{|c|}{17.62} & \multicolumn{2}{|c|}{18.47} & \multicolumn{2}{|c|}{19.24} \\
\hline
\end{tabular}

\section{Yatma}

Yulafta yatma özelliği bakımından çeșitler arasındaki farkın her iki lokasyonda da \%5 düzeyinde önemli olduğu belirlenmiștir (Çizelge 6).

Yatma, hasat sırasında tane kayıplarını artırması açısından önemli bir parametredir. Kazova lokasyonunda Seydișehir çeșidi orta, Bc Marta, Haskara çeșitleri düșük düzeyde yatma gösterirken, diğer çeșitlerde ise yatma çok az olup, Kırklar, Sarı ve Albatros çeșitlerinde yatma yoktur (Çizelge6). Samsun-Havza lokasyonunda ise; Haskara ve Seydișehir çeșitlerinde yüksek, Checota çeșidinde orta, Yeniçeri, Arslanbey, Bc Marta, Faikbey çeșitlerinde düșük oranlarda yatma tespit edilmiștir (Çizelge 6). Çalıșmamızda elde edilen sonuçlar ile araștırıcıların sonuçları benzer niteliktedir (Narlıoğlu, 2016; Sarı ve İmamoğlu, 2011).

\section{Sonuç}

Elde edilen sonuçlar doğrultusunda TokatKazova ve Samsun-Havza lokasyonlarında sırasıyla; Albatros, Faikbey ve Kırklar, Sarı çeșitleri tane verimi bakımından yüksek performans göstermiștir. Çeșitler arasında kalite bakımından Tokat-Kazova'da; Gökova ve Kahraman, Samsun-Havza lokasyonunda ise, Bc Marta çeșidi ön plana çıkmıștır. Her iki lokasyonda da Sarı çeșidi erkenci özellik göstermiștir. Samsun-Havza lokasyonunda çevresel koșulların daha uygun niteliklere sahip olmasına rağmen ortalama tane veriminin daha düșük olmasının nedeni bazı çeșitlerde meydana gelen yatma olup, belirtilen lokasyonda sağlam saplı yatmaya dayanıklı çeșitler tercih edilmelidir.

$\mathrm{Bu}$ çalıșma ile elde edilen sonuçlar lokasyonlarda üreticilerin üretim (yem-gıda) amacına göre bölgeye uygun yulaf çeșitlerini seçip verimli ve kaliteli ürün elde etmesine yardımcı olacaktır.

\section{Kaynaklar}

AACC 2000. AACC Approved Methods (10th ed.). St. Paul, MN: American Association of Cereal Chemists International

Anonim, 1986. Food and Nutrition Paper 14/7, Food Analysis: General Techniques, Additives, Contaminants, and Composition. FAOSTAT.

Anonim, 2016a. FAO

Anonim, 2016b, 2017. TÜiK

Buerstmayr H., Krenn N., Stephan U., Grausgruber $\mathrm{H}$. and Zechner E., 2007. Agronomic Performance and Quality of Oat (Avena sativa L.) Genotypes of Worldwide Origin Produced under Central European Growing Conditions. Field Crops Res., (101): 341-351 
Dumlupınar Z., 2010. Türkiye Orijinli Yerel Yulaf Genotiplerinin Avenin Proteinleri ile Morfolojik, Fenolojik ve Agronomik Özellikler Yönünden Karakterizasyonu. KSÜ Fen Bilimleri Enstitüsü Tarla Bitkileri Anabilim Dalı, Doktora Tezi, $112 \mathrm{~s}$

Dumlupınar Z., Tekin A., Herek S., Tanrıkulu A., Dokuyucu T. ve Akkaya A. 2017. Türkiye Kökenli Yulaf Genotiplerinin Bazı Tarımsal Özellikler Bakımından Değerlendirilmesi. Türk Tarım Gıda Bilim ve Teknoloji Dergisi, 5(7): 763-772

Ercan K., Tekin A., Herek S., Kurt A., Kekeç E., Olgun M.F., Dokuyucu T. ve Akkaya A., 2016. Yerel Yulaf Hatlarının Kahramanmaraș Koșullarındaki Performansı. K.S.Ü Doğa Bilimleri Dergisi, 19(4), 438-444

Güngör H., Dokuyucu T., Dumlupınar Z. ve Akkaya A., 2017. Yulafta (Avena spp.) Tane Verimi ile Bazı Tarımsal Özelikler Arasındaki İlișkilerin Korelasyon ve Path Analizleriyle Saptanması. Tekirdağ Ziraat Fakültesi Dergisi, 14(01)

Hischke H.H., Potter G.C. and Graham W.R., 1968. Nutritive Value of Oat Protein. I. Varietal Differences as Measured by Amino Acid Analysis and Rat Growth Responces. The Quaker Oats Company, John Stuart Research Laboratory, Barrington

Iannucci A., Codianni P. and Cattivelli L., 2011. Evaluation of genotype diversity in oat germplasm and definition of ideotypes adapted to the mediterranean environment. Article ID 870925. doi: 10.1155/2011/870925

İnan A.S., Özbaș M.O. ve Çağırgan M.İ., 2005. İnsan Beslenmesinde Kullanılan Yulaf Hatlarının Tarımsal ve Kalite Özellikleri Bakımından Değerlendirilmesi. Türkiye VI. Tarla Bitkileri Kongresi. 5-6 Eylül 2005, Antalya Cilt II: 1153-1155

Kahraman T., Avcı R., Öztürk i. ve Tülek A., 2012. Trakya-Marmara Bölgesine Uygun Yulaf Genotiplerinin Belirlenmesi. Tarım Bilimleri Araștırma Dergisi Tarım Sempozyumu Özel Sayısı (Prof. Dr. Selahattin İptaș anısına) 5 (2): 24-28

Kara R., Dumlupınar Z., Hıșır Y., Dokuyucu T. ve Akkaya A., 2007. Kahramanmaraș Koșullarında Yulaf Çeșitlerinin Tane Verimi ve Verim Unsurları Bakımından Değerlendirilmesi.Türkiye VII. Tarla Bitkileri Kongresi, 25-27 Haziran, Erzurum (Sunulu Bildiri), 121-125

Kün E., 1996. Tahıllar-I (Serin İklim Tahılları). Ankara Üniv. Ziraat Fakültesi Yayınları, Yayın No:1451, Ankara

Locatelli A.B., Federizzi L.C., Milach S.C.K. and McElroy A. R. 2008. Flowering Time in Oat: Genotype Characterization for Photoperiod and Vernelization Response. Field Crops Res., 106: 242-247
Maral H., 2009. Yulaf Çeșitlerinin Azotlu Gübrelemeye Tane Verimi, Azot Kullanımı ve Verim Özellikleri Yönünden Tepkisi. K.S.Ü. Fen Bilimleri Enstitüsü, Tarla Bitkileri Anabilim Dalı, Yüksek Lisans Tezi, Kahramanmaraș, 61s

Mut Z., Akay H., Sezer I.., Gülümser A., Öner F. ve Erbaș Ö., 2011. Farklı Orijinli Yulaf (Avena sativa L) Genotiplerinin Samsun Ekolojik Koșullarında Tarımsal ve Bazı Kalite Özelliklerinin Tespiti. 9. Tarla Bitkileri Kongresi. 12-15 Eylül, Bursa, 88-93

Narlığlu A., 2016. Bazı Yulaf Genotiplerinin Verim ve Kalite Kriterleri ile Silaj Özellikleri Bakımından Değerlendirilmesi. K.S.Ü. Fen Bilimleri Enstitüsü, Tarla Bitkileri Anabilim Dalı, Yüksek Lisans Tezi, Kahramanmaraș, $72 \mathrm{~s}$

Nawaz N., Razzaq A., Ali Z., Sarwar G. and Yousaf M., 2004. Performance of Different Oat (Avena sativa L.) Variteties under the Agro-Climatic Conditions of Bahawalpur-Pakistan. Int. J. Agri. Biol., 6(4): 624-626

Peltonen-Sainio P. and Jarvinen P., 1995. Seeding Rate Effects on Tillering, Grain Yield, and Yield Components of Oat at High Latitude. Field Crops Res., 40, 49-56

Sabandüzen B. ve Akçura M., 2017. Bazı Yulaf Genotiplerinin Çanakkale Koșullarında Verim ve Verim İncelenmesi. Türk Tarım ve Doğa Bilimleri Dergisi 4(2): 101-108

Sarı N. ve İmamoğlu A., 2011. Menemen Ekolojik Koșullarına Uygun İleri Yulaf Hatlarının Belirlenmesi. Journal of AARI 21 (1), 16-25

Sarı N., İmamoğlu A. ve Yıldız Ö., 2012. Menemen Ekolojik Koșullarında Bazı Ümitvar Yulaf Hatlarının Verim ve Kalite Özellikleri. Journal of AARI 22 (1), 18-32

Tamm I., 2003. Genetic and Environmental Variation of Grain Yield of Oat Varieties. Agronomy Research, 1: 93-97

Yılmaz N., 1996. Van Ekolojik Koșullarında Bazı Yulaf Çeșit ve Hatlarının Verim ve Verim Öğeleri Üzerinde Bir Araștırma. Türkiye 3. Çayır Mer’a ve Yem Bitkileri Kongresi 17-19 Haziran 1996, Erzurum

Zute S. and Bulbyks P. 1996. The Quality Characteristics of New Varieties of Oats. In: Slinkard A., Scoles, G., Rosnagel, B. (Editors), V International Oat Conference \& VII International Barley Genetics Symposium, Poster Sessions Vol 1, University Extension Press, s. 150-151, Saskatchewan 